\title{
IS TWIN PREGNANCY, CALVING AND PREGNANCY LOSS PREDICTABLE BY SERUM PREGNANCY-SPECIFIC PROTEIN B (PSPB) CONCENTRATION 28-35 DAYS AFTER AI IN DAIRY COWS?
}

\author{
Zoltán SZELÉNYI ${ }^{1,2}$, Orsolya Gabriella BALOGH ${ }^{3}$, Fernando LOPEZ-GATIUS ${ }^{4}$, \\ Irina GARCIA-ISPIERTO ${ }^{4}$, Eszter KRIKÓ ${ }^{5}$ and György GÁBOR ${ }^{3 *}$ \\ ${ }^{1}$ Department and Clinic of Farm Animal Medicine, University of Veterinary Medicine \\ and ${ }^{2}$ MTA-SZIE Large Animal Clinical Research Group, Üllö, Dóra major, Hungary; \\ ${ }^{3}$ National Agricultural Research and Innovation Center, Research Institute for Animal \\ Breeding, Nutrition and Meat Science, Gesztenyés u. 1, H-2053 Herceghalom, Hungary; \\ ${ }^{4}$ Universitat de Lleida, and Agrotecnio Center, Lleida, Spain, ${ }^{5}$ Centre for Bioinformatics, \\ University of Veterinary Medicine, Budapest, Hungary
}

(Received 16 February 2018; accepted 25 July 2018)

Double ovulation occurs more frequently in multiparous cows with high milk production than in primiparous cows and the rate of twin pregnancy/calving is increasing worldwide. Diagnosis of twin pregnancy is possible by ultrasound at the time of early pregnancy examination [28-34 days after artificial insemination (AI)]. Pregnancy proteins are also well-known indicators of gestation. The risk of pregnancy loss during the first trimester of gestation for cows carrying twins is three to nine times higher than for cows carrying singletons. Pregnancy-specific protein B (PSPB) is a good indicator not only of pregnancy but also of pregnancy loss. The aims of this study were (a) to collect calving data in some Hungarian HolsteinFriesian herds $(n=7,300)$ to compare PSPB serum concentrations (measured 29-35 days post insemination) in twin- and singleton-calving cows (Trial 1), and (b) to check the predictive value of PSPB serum concentration for twin pregnancy and pregnancy loss in high-producing Spanish Holstein-Friesian cows ( $=$ 98; Trial 2). Our results showed almost 7\% twin calving rate. Although hormonal treatments are commonly believed to be major causes of twin pregnancies, our data do not support this hypothesis. The only exception is the single PGF injection, which significantly increased twin calving. No effect of milk production on the risk of twin pregnancy was found, and twin pregnancy increased with parity. The AI bull, the bull's sire, the bull's grandfather and the cow's father also affected twin calving $(\mathrm{P} \leq 0.02)$. We found much higher frequency of twin calving in cows diagnosed pregnant with higher than $3 \mathrm{ng} / \mathrm{ml}$ serum PSPB concentrations at 29-35 days after insemination. In Trial 2, non-significant but well-marked differences were found in PSPB serum concentration between singleton- and twin-pregnant cow samples (2.1 and $2.9 \mathrm{ng} / \mathrm{ml})$ at different bleeding times. Probably the small size of the study population and the effects of milk production on PSPB values may explain this lack of significance.

*Corresponding author: E-mail: h12617gab@helka.iif.hu; Phone: 0036 (23) 319-133; Mobile: 0036 (20) 9745-162 

tle, PSPB

Key words: Ultrasound pregnancy diagnosis, early fetal period, dairy cat-

The apparent milk yield per dairy cow increased by $1.5 \%$ in the EU-28 from 2014 to 2015, almost reaching 6,900 kg per dairy cow (Eurostat, 2016). In Hungary the standard lactation production increased by approx. $700 \mathrm{~kg}$ between 2013 and 2016, and it has almost reached 10,000 kg/cow/year recently (Standard lactations - Hungarian Holstein-Friesian Breeders' Association homepage, Annual Report 2017). This large improvement of milk production can be attributed to the intensive genetic selection for milk production (especially genomic selection). High milk production is believed to be associated with declining fertility rates and a longer calving to conception interval (Lucy, 2001; López-Gatius, 2003). Moreover, in the past four decades the rate of twin calving also increased (Kinsel et al., 1998; Silva de Rio et al., 2007) due to the increase of multiple ovulation associated with the high milk yield (Fricke and Wiltbank, 1999; López et al., 2005) and with some synchronisation protocols (Andreu-Vázquez et al., 2012a). Twin pregnancy is undesirable due to the high risk of pregnancy loss, placenta retention, involution disorders and freemartinism (López-Gatius et al., 2017).

The rate of twin pregnancy/calving is increasing worldwide and some papers report extremely high occurrence (17.9\% in Spain - Andreu-Vázquez et al., $2012 a$ ) at the time of the early pregnancy detection or twin delivery in $12 \%$ of the cows (Silva del Rio et al., 2007). Double ovulation occurs more frequently in multiparous cows with high milk production than in primiparous cows (Fricke and Wiltbank, 1999; López-Gatius et al., 2005; Kusaka et al., 2017).

Diagnosis of twin pregnancy is possible by ultrasound at the time of early pregnancy examination [28-34 days after artificial insemination (AI) - LópezGatius et al., 2004]. The risk of pregnancy loss during the first trimester of gestation for cows carrying twins is three to nine times higher than for cows carrying singletons (López-Gatius et al., 2002, 2009; López-Gatius and Garcia-Ispierto, 2010). Pregnancy proteins are also well known indicators of gestation. Nowadays not only blood (Sasser et al., 1986; Humblot et al., 1988; Zoli et al., 1991; Romano and Larson, 2010) but also milk tests are available (Friedrich and Holtz, 2010) for the detection of early pregnancy in ruminants. Pregnancy-specific protein B (PSPB) is a good indicator not only of pregnancy, but pregnancy loss as well (Gábor et al., 2016). Although some data were published about the application of pregnancy-associated protein for twin pregnancy diagnosis (Szelényi et al., 2015; Garcia Ispierto et al., 2016), but its usefulness on practical level is still questionable.

The aims of our study were (a) to collect calving data in Hungarian Holstein-Friesian herds to compare PSPB serum concentration (measured 29-35 days post insemination) in twin- and singleton-calving cows and (b) to check the predictive value of PSPB serum concentration for twin pregnancy and pregnancy loss in high-producing Spanish Holstein-Friesian cows. 


\section{Materials and methods}

\section{PSPB detection}

In all experiments, a blood sample from each cow was collected from the coccygeal blood vessels 29-35 days after insemination, and sent to a routine laboratory (Androvet, Budapest, Hungary) by overnight mail. Upon arrival at the laboratory, blood samples were centrifuged (2000 rpm for $10 \mathrm{~min}$ ) and the resulting sera were assayed for Pregnancy-Specific Protein B (BioPRYNTM; BioTracking, Moscow, ID, USA), as described earlier (Gábor et al., 2007). Cows with serum PSPB concentrations $>1.1 \mathrm{ng} / \mathrm{ml}$ were considered pregnant, those with $<0.6 \mathrm{ng} / \mathrm{ml}$ were considered nonpregnant, and those with concentrations between 0.6 and $1.1 \mathrm{ng} / \mathrm{ml}$ were deemed to be at a high risk of pregnancy loss. In all cows initially designated pregnant, continuation of pregnancy or pregnancy loss were determined by transrectal palpation 60-70 days after AI.

Trial 1. Samplings for PSPB examinations on days 29-35 after AI were performed on three large Hungarian dairy farms (average herd sizes and milk production ranged from 800 to 1100 cows and from 9,500 to $10,850 \mathrm{~kg} / \mathrm{cow} /$ year, respectively) and PSPB determinations were carried out routinely in the Androvet laboratory between April 2012 and May $2016(\mathrm{n}=7300)$. In that period, cows with twin calving were recorded in the sampled herds. Data of AIs resulting in twin calving were collected (serum PSPB concentration, date of the AI, parity, milk production and body condition score by the time of the AI, AI bull, the father of the cow, hormonal treatments before the AI, daily temperature data) in a self-developed database (Bopella).

Trial 2. Blood samples were collected from 98 dairy cows on two highproducing dairy farms (1100 and 750 cows, respectively) in Northeastern Spain. Cows were examined by transrectal ultrasound (EasyScan, BCF Technologies, United Kingdom) three times: between 29-35, 36-42 and 43-49 days after AI. The ovaries and uterus were examined and pregnancy was confirmed by the identification of one/two embryo(s) and embryonic heartbeat and the presence of a corpus luteum/two corpora lutea on the ipsilateral ovary. Within the weekly reproductive visit, for every two cows carrying live twins one cow with one embryo was added to the study, because singletons were only control animals. At the time of pregnancy diagnosis blood samples were collected from the coccygeal vein. Serum samples were sent to the Androvet laboratory on dry ice and assayed for PSPB concentration as described above. The diagnosis of pregnancy loss was based on the last two ultrasound examinations (35-41 and 43-49 days post AI, respectively). 


\section{Statistical analysis}

The association of the binary outcomes and the independent variables was analysed by logistic regression (Gelman and Hill, 2006). Prediction performance was evaluated by ROC analysis, while the chi-square test was used to determine relationships between categorical variables. Normality of the distribution of serum PSPB concentrations was tested (Shapiro-Wilk normality test). Depending on the normality of the data Student's $t$-test or Wilcoxon rank sum test was used for mean/median serum PSBP concentrations of cows calving twins or singletons and a basic comparison (Table 1). All data analyses were performed using the $\mathrm{R}$ language and environment (R Core Team, 2017; R: A language and environment for statistical computing. R Foundation for Statistical Computing, Vienna, Austria. URL https://www.R-project.org/).

\section{Table 1}

Detailed information about serum PSPB concentrations (normality of the distribution, mean/median, standard deviation and interquartile range)

\begin{tabular}{|c|c|c|c|c|c|c|c|c|c|c|c|c|c|}
\hline & \multicolumn{13}{|c|}{ Trial 1} \\
\hline & \multicolumn{6}{|c|}{ Singletons } & \multicolumn{7}{|c|}{ Twins } \\
\hline & $\mathrm{N}$ & mean & SD & median & IQR & $\begin{array}{c}\text { Normality } \\
\text { test }^{*} \\
\text { (P) }\end{array}$ & $\mathrm{N}$ & mean & SD & median & IQR & $\begin{array}{l}\text { Normality } \\
\text { test }^{*} \\
\text { (P) }\end{array}$ & Test $^{* *}$ \\
\hline & 6372 & 2.88 & 1.38 & 2.65 & 1.26 & $<0.001$ & 469 & 3.79 & 1.83 & 3.50 & 1.42 & $\begin{array}{c}\mathrm{P}< \\
0.001\end{array}$ & $\begin{array}{c}\mathrm{P}< \\
0.001\end{array}$ \\
\hline & \multicolumn{13}{|c|}{ Trial 2} \\
\hline PSPB 1 & 34 & 2.10 & 1.03 & 2.03 & 1.56 & 0.035 & 64 & 2.90 & 0.87 & 2.90 & 1.25 & 0.129 & 0.0002 \\
\hline PSPB 2 & 34 & 1.77 & 1.05 & 1.60 & 1.73 & 0.075 & 61 & 2.52 & 0.74 & 2.53 & 1.16 & 0.48 & 0.0005 \\
\hline PSPB 3 & 15 & 1.97 & 0.64 & 1.95 & 0.85 & 0.969 & 58 & 2.15 & 0.67 & 2.00 & 1.07 & 0.0478 & 0.5526 \\
\hline
\end{tabular}

*Shapiro-Wilk normality test; ${ }^{* *}$ Depending on the normality of the data Student's $t$-test or Wilcoxon rank sum test was used; IQR: interquartile range

\section{Results}

\section{Trial 1}

Examination of 7300 deliveries showed a $6.4 \%$ twin calving rate in the three herds (Table 2). Differences in the distribution of serum PBSP concentrations for cows calving twins and singletons are shown in Fig. 1. The logistic regression analysis of hormonal treatments prior to AI also indicates differences: the highest twin calving rate occurred after PGF treatment (OR: 1.44, 95\% CI: $1.10-1.86, \mathrm{P}=0.0076$ ), while the lowest twin calving rate could be observed followed the Provsynch (PreSync plus Ovsynch; OR: 0.59, 95\% CI: 0.40-0.85, P = 0.0026) protocol (Table 2). 
Table 2

Twin calving and hormonal treatments in Trial 1

\begin{tabular}{lrrrrrr}
\hline & Singleton & Twin & Total & Twin, \% & Odds ratio & $95 \%$ CI \\
\hline AI after spontaneous heat & 4253 & 291 & 4544 & $6.4^{\mathrm{A}}$ & - & - \\
AI after Provsynch protocol & 843 & 35 & 878 & $4.0^{\mathrm{B}}$ & 0.59 & $0.40-0.85$ \\
AI after Ovsynch protocol & 876 & 60 & 936 & $6.4^{\mathrm{A}}$ & 1.001 & $0.74-1.34$ \\
AI after single PGF2 $\alpha$ injection & 860 & 82 & 942 & $8.7^{\mathrm{C}}$ & 1.44 & $1.10-1.86$ \\
\hline Total & 6832 & 468 & 7300 & 6.4 & - & -
\end{tabular}

${ }^{\mathrm{A}-\mathrm{C}}$ Between adjacent rows, numbers without a common superscript differed significantly $(\mathrm{P}<0.05)$; CI: confidence interval

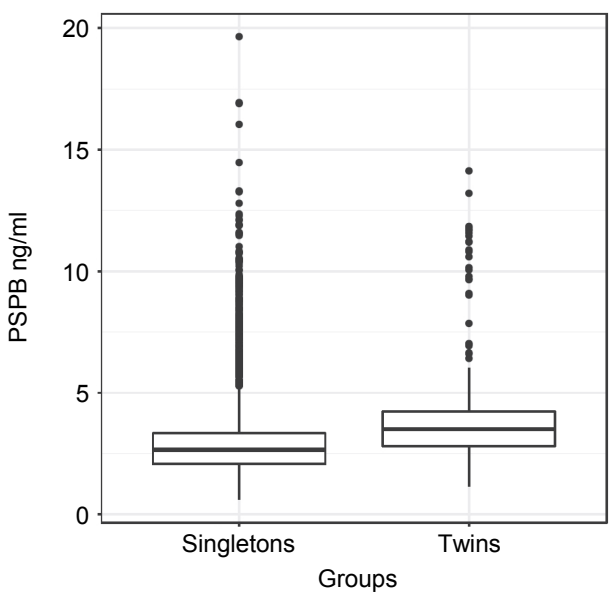

Fig. 1. Differences in the distribution of serum PBSP concentrations for cows calving twins and singletons (Trial 1)

More detailed statistical analysis of the pedigree, breeding and reproduction data demonstrates that high PSPB concentration (29-35 days after AI) significantly correlates with twin calving rate $(\mathrm{OR}=1.31 ; \mathrm{P}<0.0001$; Table 3 , Fig. $2)$. The positive predictive value of the cut-off $(3 \mathrm{ng} / \mathrm{ml})$ using logistic regression (OR: 3.84, 95\% CI: 3.15-4.71, $\mathrm{P}<0.0001$ ) for the risk of twin calving in cows with serum PSPB values higher than $3 \mathrm{ng} / \mathrm{ml}$ is 0.12 (95\% CI: $0.11-0.14$ ), the negative predictive value is 0.96 (95\% CI: $0.96-0.97)$. Genetics also seems to have a significant effect on twin calving (AI bull: $\mathrm{P}=0.017$, bull's sire: $\mathrm{P}=0.02$, bull grandfather: $\mathrm{P}=0.0007$, cow's father: $\mathrm{P}=0.016$ ). The number of AIs, the body condition score (BCS), daily temperature and daily milk production by the time of the $\mathrm{AI}$ and the age of the cow had no significant effect on twin calving. 
Table 3

Twin calving and serum PSPB concentrations in Trial 1

\begin{tabular}{lccc}
\hline $\begin{array}{l}\text { Serum PSPB concentrations } \\
(\mathrm{ng} / \mathrm{ml})\end{array}$ & $\begin{array}{c}\text { Pregnant } \\
\text { samples }\end{array}$ & $\begin{array}{c}\text { Twin } \\
\text { calving }\end{array}$ & $\%$ \\
\hline $0.6-1.1$ & 136 & 0 & 0.0 \\
$1.101-2$ & 1492 & 29 & 1.9 \\
$2.001-3$ & 2895 & 120 & 4.1 \\
$3.001-4$ & 1738 & 154 & 8.9 \\
$4.001-$ & 928 & 166 & 17.9 \\
\hline
\end{tabular}

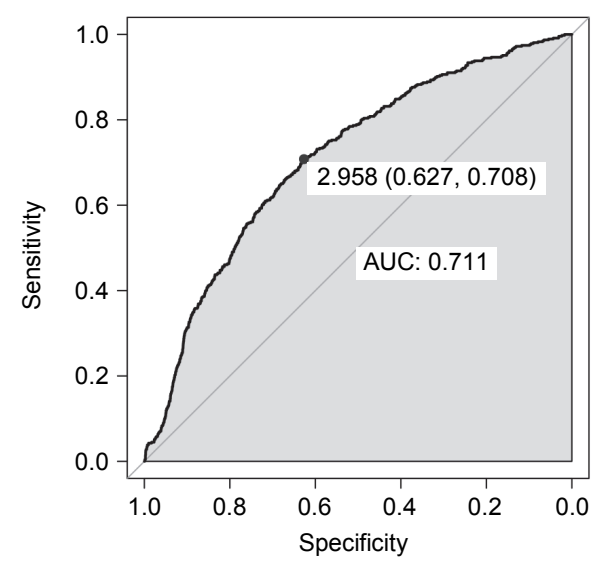

Fig. 2. ROC analysis of twin calving and serum PSPB concentration (Trial 1)

Trial 2

The main results of Trial 2 are summarised in Tables 4 and 5, and in Fig. 3. Ninety-eight pregnant cows were included in the study 29-35 days after AI: 64 twin and 34 singleton pregnancies were diagnosed by transrectal ultrasound. Daily milk production at the time of pregnancy diagnosis (mean of the three previous days $\pm \mathrm{SD}$ ) for these cows was $40.9 \pm 8.4 \mathrm{~kg}$, ranging from 18 to $62 \mathrm{~kg}$. One week later three pregnancy losses were diagnosed out of the 64 twin pregnancies (4.4\% pregnancy loss). Between days 43-49 after AI another three and 19 losses of twin and single pregnancies were detected $(4.6 \%$ and $55.9 \%$ pregnancy loss, respectively). All ultrasound-based pregnancy diagnoses were confirmed by the results of the Biopryn test (serum PSPB concentration). Although serum PSPB concentration differed between singleton- and twin-pregnant cows, the differences were not significant. Statistical analysis showed that cows with higher parity have a lower risk for twin pregnancy $(\mathrm{P}=0.023)$. Open days, number of AIs and milk production had no effect on the twinning rate. Parity had a significant impact on pregnancy loss, since cows with more calvings had higher pregnancy loss $(20 \%$ vs. $28.6 \%, \mathrm{P}<0.05)$. 
Table 4

Odds ratios (OR) and $\mathrm{P}$ values for twin pregnancy (Trial 2)

\begin{tabular}{lcc}
\hline & OR for twin pregnancy & P value \\
\hline PSPB threshold 3 ng/ml & 3.62 & 0.009 \\
Daily milk production & 0.94 & 0.130 \\
Number of AIs & 1.03 & 0.819 \\
Open days & 1.01 & 0.753 \\
Primiparous & 1.02 & 0.930 \\
Multiparous & 0.16 & 0.023 \\
\hline
\end{tabular}

Table 5

Pregnancy loss in twin- and singleton-pregnant cows in Trial 2

\begin{tabular}{lccccc}
\hline & \multicolumn{2}{c}{ Primiparous } & & \multicolumn{2}{c}{ Multiparous } \\
\cline { 2 - 3 } \cline { 5 - 6 } & Pregnant & Pregnancy loss & & Pregnant & Pregnancy loss \\
\hline Singleton & 5 & 3 & & 29 & 16 \\
Twin & 30 & 4 & & 34 & 2 \\
\hline Total & 35 & 7 & & 63 & 18 \\
\hline Prenancy loss $\%$ & & $20.0 \%{ }^{\mathrm{A}}$ & & $28 . \%^{\mathrm{B}}$ \\
\hline
\end{tabular}

${ }^{\mathrm{A}-\mathrm{B}}$ Between adjacent columns, numbers without a common superscript differed significantly $(\mathrm{P}<0.05)$

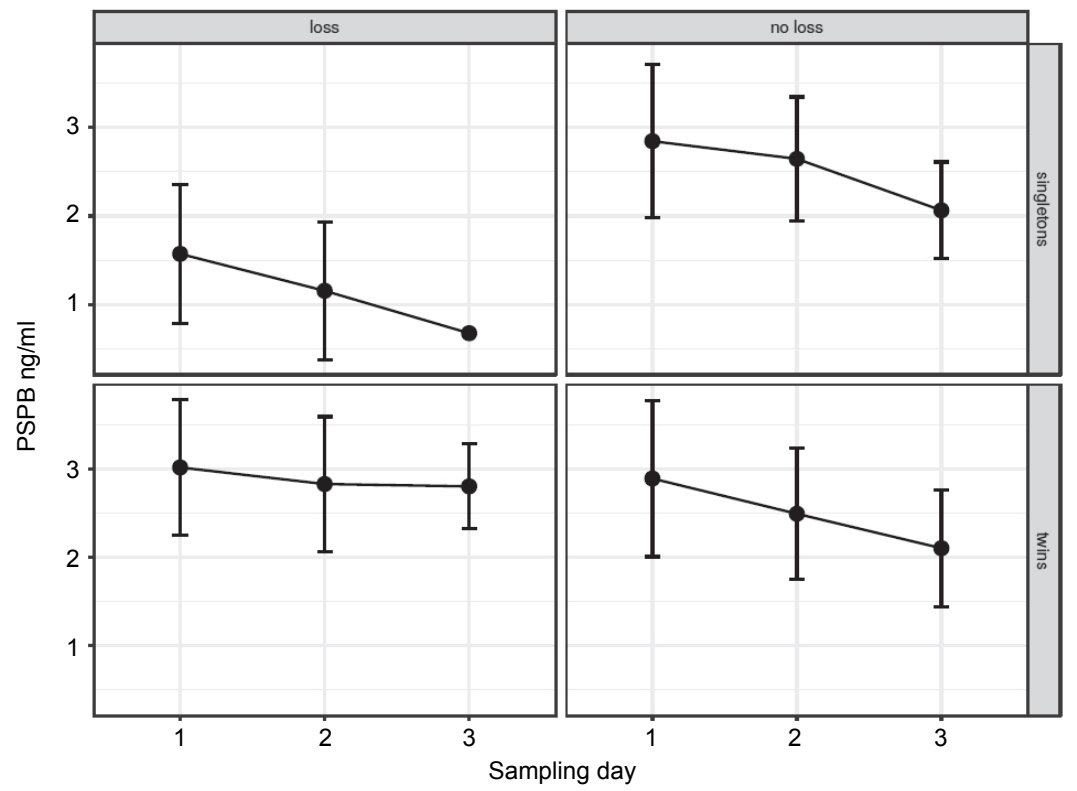

Fig. 3. Serum PSPB concentrations in twin- and singleton-pregnant cows in Trial 2 (sampling day 1: 29-35 days post AI; sampling day 2: 36-42 days post AI; sampling day 3: $43-49$ days post AI) 


\section{Discussion}

Twinning in the dairy cattle population appears to be increasing over time (Kinsel et al., 1998; Johanson et al., 2001; López-Gatius et al., 2017). If this trend continues, the dairy industry must be prepared to cope with the negative effects associated with twinning (Fricke, 2001). In the late 1950s and early 1960s the incidence of twinning was approx. 1\% in dairy cattle (Noakes, 2009) and it significantly increased over the past decades along with the increase in milk production (Nielen et al., 1989). Our results (Table 2) showed a similar trend and we recorded almost $7 \%$ twin calving rate in the three herds. This is definitely a much higher twin calving rate than observed earlier (1-5\% depending on the breed; Horn, 1973). Although it is a common belief that hormonal treatments are the major causes of twin pregnancies, our data do not support this hypotheses. The only exception is the single PGF injection and this is in agreement with the findings of Andreu-Vázquez et al. (2012a) who reported that only those oestrus synchronisation protocols used before AI affected the twin pregnancy rate in which PGF was used together with other hormones (PRID, eCG). PGF alone (Kinsel et al., 1998) or in combination with FSH/LH or GnRH (Nielen et al., 1989) increased the risk of twinning. No effect of milk production on the risk of twin pregnancy was found, in agreement with a previous study (Andreu-Vázquez et al., 2012b). The likelihood of twin pregnancy increases with parity. Older cows have been described to be more likely to deliver twins (Cady and Van Vleck, 1978; Nielen et al., 1989; Eddy et al., 1991; Kinsel et al., 1998; Andreu-Vázquez et al., 2012b). Our results showed that the AI bull, the bull's sire, the bull's grandfather and the cow's father also affected twin calving $(\mathrm{P} \leq 0.02)$. Johanson et al. (2001) analysed the calving data of North American Holsteins [1,324,678 births of 37,174 sires of cows from the National Association of Animal Breeders (NAAB) calving ease database]. Heritability estimates for the sire of the cow effect were $2.10 \%$ by the linear model analysis and $8.71 \%$ by the threshold model analysis. The predicted transmitting abilities (PTA) of sires for twinning rate ranged from 1.6 to $8.0 \%$. The authors concluded that sire selection can be used to reduce the incidence of twins and also the increased cost of production associated with twins.

In our study we found a much higher frequency of twin calving in cows diagnosed pregnant with more than $3 \mathrm{ng} / \mathrm{ml}$ serum PSPB concentrations at 29-35 days after insemination (Table 3). Although individual differences could be detected, the trend was similar to the results of others who stated that cows bearing twins showed significantly higher plasma PAG-I (López-Gatius et al., 2007) or plasma PAG I, PAG-II and P4 concentrations (Garcia-Ispierto et al., 2016) throughout the study period than cows bearing singletons.

Although there was a significant difference in PSPB serum concentration between singleton and twin pregnancies on the first two sampling days (Table 1) 
in Trial 2, overall the differences in PSPB serum concentration were nonsignificant between singleton- and twin-pregnant samples $(2.1$ and $2.9 \mathrm{ng} / \mathrm{ml})$. Probably the low size of the study population and the effects of milk production on PSPB values may explain this lack of significance. Daily milk production at the time of pregnancy diagnosis slightly exceeded $40 \mathrm{~kg}$, and milk production correlated negatively with plasma PAG-I values in a previous study (LópezGatius et al., 2007). Although a lower pregnancy loss rate (9.4\%) was recorded in twin-pregnant than in singleton-pregnant $(55.9 \%)$ cows (in these cases small morphological abnormalities such as smaller amount of amniotic fluid and smaller size of the embryo were seen), twin pregnancy is undoubtedly a high risk factor for the termination of pregnancy in cattle (López-Gatius and Hunter, 2017; López-Gatius et al., 2017). Statistical analysis showed a lower risk of twin pregnancy in higher parity cows $(\mathrm{P}=0.023)$, but several other data confirm (Johanson et al., 2001; Gábor et al., 2016) that in this case it is an accidental finding probably caused by the relatively low number of cases. All other findings (i.e. that the number of open days, the number of AIs and milk production had no effect on twin pregnancy) are supported by the results of earlier researches. Not surprisingly, parity has an impact on pregnancy loss (Table 5), since cows with more calvings had a higher pregnancy loss $(20 \%$ vs. $28.6 \%, \mathrm{P}<0.05)$.

Although we also do not have a clear explanation for the decrease of serum PSPB concentrations at the different blood sampling times, an apparent decline in plasma PA-I values on day 42 of gestation was previously described (López-Gatius et al., 2007). This is not surprising in view of the fact that PAG molecules are a family of closely related proteins whose expression patterns vary temporarily during different periods of gestation (Green et al., 2000; Garbayo et al., 2008).

After analysing the twin calving data in some Hungarian Holstein-Friesian herds we can conclude that twinning rate rapidly increased over the past decades as well and it seems that more genetic than management (e.g. hormonal treatments) factors could be identified in the background of this unwanted change. Under our conditions, no real predictive value of PSPB was found for twin pregnancy or pregnancy loss, probably due to the relatively low number of experimental animals and the negative effect of high milk production on PSPB values in Trial 2. However, we found that lower PSPB serum concentration 29-35 days post AI represents a high risk for pregnancy loss as reported in a previous paper (based on the analysis of approx. 140 thousand data; Gábor et al., 2016).

\section{References}

Andreu-Vázquez, C., Garcia-Ispierto, I. and López-Gatius, F. (2012a): Photoperiod length and the estrus synchronization protocol used before AI affect the twin pregnancy rate in dairy cattle. Theriogenology 78, 1209-1216. 
Andreu-Vázquez, C., Garcia-Ispierto, I., Fricke, P. M. and López-Gatius, F. (2012b): Effects of twinning on the subsequent reproductive performance and productive lifespan of highproducing dairy cows. Theriogenology $\mathbf{7 8}, 2061-2070$.

Cady, R. A. and Van Vleck, L. D. (1978): Factors affecting twinning and effects of twinning in Holstein dairy cattle. J. Anim. Sci. 46, 950-956.

Eddy, R. G., Davies, O. and David, C. (1991): An economic assessment of twin births in British dairy herds. Vet. Rec. 129, 526-529.

Eurostat (2016): Milk and Milk Product Statistics. http://ec.europa.eu/eurostat/statistics-explained/ index.php/Milk_and_milk_product_statistics

Fricke, P. M. (2001): Twinning in dairy cattle. The Professional Animal Scientist 17, 61-67.

Fricke, P. M. and Wiltbank, M. C. (1999): Effect for milk production on the incidence of double ovulation in dairy cows. Theriogenology 52, 1133-1143.

Friedrich, M. and Holtz, W. (2010): Establishment of an ELISA for measuring Bovine PregnancyAssociated Glycoprotein in serum or milk and its application for early pregnancy detection. Reprod. Domest. Anim. 45, 142-146.

Gábor, G., Kastelic, J. P., Abonyi-Tóth, Z., Gábor, P., Endrődi, T. and Balogh, O. G. (2016): Pregnancy loss in dairy cattle: relationship of ultrasound, blood Pregnancy-Specific Protein B, progesterone and production variables. Reprod. Domest. Anim. 51, 467-473.

Gábor, G., Tóth, F., Ózsvari, L., Abonyi-Tóth, Z. and Sasser, R. G. (2007): Early detection of pregnancy and embryonic loss in dairy cattle by ELISA tests. Reprod. Domest. Anim. 42, 633-636.

Garbayo, J. M., Serrano, B. and Lopez-Gatius, F. (2008): Identification of novel pregnancyassociated glycoproteins (PAG) expressed by the peri-implantation conceptus of domestic ruminants. Anim. Reprod. Sci. 103, 120-134.

García-Ispierto, I., Rosselló-Visa, M. A., Serrano-Pérez, B., Mur-Novales, R. and López-Gatius, F. (2016): Plasma concentrations of pregnancy-associated glycoproteins I and II and progesterone on day 28 post-AI as markers of twin pregnancy in dairy cattle. Liv. Sci. 192, 44-47.

Gelman, A. and Hill, J. (2006): Data Analysis Using Regression and Multilevel/Hierarchical Models. Cambridge University Press, Cambridge, UK.

Green, J. A., Xie, S., Quan, X., Bao, B., Gan, X. and Mathialagan, N. (2000): Pregnancyassociated bovine and ovine glycoproteins exhibit spatially and temporally distinct expression patterns during pregnancy. Biol. Reprod. 62, 1624-1631.

Horn, A. (1973): The bases of the quantitative and qualitative reproduction of the cattle population. In: Horn, A. (ed.) Cattle Breeding [in Hungarian]. Mezőgazdasági Kiadó, Budapest. pp. $627-629$.

Hungarian Holstein-Friesian Breeders' Association (2017): Standard Lactations Annual Report 2017. https://www.holstein.hu/index.php/laktorsz

Humblot, P., Camous, S., Martal, J., Charlery, J., Jeanguyot, N., Thibier, M. and Sasser, R. G. (1988): Pregnancy-specific protein B, progesterone concentrations and embryonic mortality during early pregnancy in dairy cows. J. Reprod. Fertil. 83, 215-223.

Johanson, J. M., Berger, P. J., Kirkpatrick, B. W. and Dentine, M. R. (2001): Twinning rates for North American Holstein sires. J. Dairy Sci. 84, 2081-2088.

Kinsel, M. L., Marsh, W. E., Ruegg, P. L. and Etherington, W. G. (1998): Risk factors for twinning. J. Dairy Sci. 81, 989-993.

Kusaka, H., Miura, H., Kikuchi, M. and Sakaguchi, M. (2017): Incidence of double ovulation during the early postpartum period in lactating dairy cows. Theriogenology 91, 98-103.

López, H., Caraviello, D. Z., Satter, L. D., Fricke, P. M. and Wiltbank, M. C. (2005): Relationship between level of milk production and multiple ovulations in lactating dairy cows. J. Dairy Sci. 88, 2783-2793.

López-Gatius, F. (2003): Is fertility declining in dairy cattle? A retrospective study in northeastern Spain. Theriogenology 60, 89-99. 
López-Gatius, F. and Garcia-Ispierto, I. (2010): Ultrasound and endocrine findings that help to assess the risk of late embryo/early foetal loss by non-infectious cause in dairy cattle. Reprod. Domest. Anim. 45, Suppl. 3, 15-24.

López-Gatius, F. and Hunter, R. H. F. (2017): From pre-ovulatory follicle palpation to the challenge of twin pregnancies: Clinical reflections following one million gynaecological examinations in dairy cows. Reprod. Domest. Anim. 52, Suppl. 4, 4-11.

López-Gatius, F., Andreu-Vázquez, C., Mur-Novales, R., Cabrera, V. E. and Hunter, R. H. F. (2017): The dilemma of twin pregnancies in dairy cattle. A review of practical prospects. Liv. Sci. 197, 12-16.

López-Gatius, F., Garbayo, J. M., Santolaria, P., Yániz, J., Ayad, A., de Sousa, N. M. and Beckers, J. F. (2007): Milk production correlates negatively with plasma concentrations of pregnancy-associated glycoprotein (PAG) during the early fetal period in high producing dairy cows with live fetuses. Domest. Anim. Endocrinol. 32, 29-42.

López-Gatius, F., López-Béjar, M., Fenech, M. and Hunter, R. H. F. (2005): Ovulation failure and double ovulation in dairy cattle: risk factors and effects. Theriogenology 63, 1298-1307.

López-Gatius, F., Santolaria, P., Yániz, J. L., Garbayo, J. M. and Hunter, R. H. (2004): Timing of early foetal loss for single and twin pregnancies in dairy cattle. Reprod. Domest. Anim. 39, 429-433.

López-Gatius, F., Santolaria, P., Yániz, J., Rutllant, J. and López-Béjar, M. (2002): Factors affecting pregnancy loss from gestation day 38 to 90 in lactating dairy cows from a single herd. Theriogenology 57, 1251-1261.

López-Gatius, F., Szenci, O., Bech-Sàbat, G., Garcia-Ispierto, I., Serrano, B., Santolaria, P. and Yániz, J. (2009): Factors of non-infectious nature affecting late embryonic and early foetal loss in high producing dairy herds in north-eastern Spain [in Hungarian, with English abstract]. Magy. Allatorvosok 131, 515-531.

Lucy, M. C. (2001): ADSA Foundation Scholar Award - Reproductive loss in high-producing dairy cattle: Where will it end? J. Dairy Sci. 84, 1277-1293.

Nielen, M., Schukken, Y. H., Scholl, D. T., Wilbrink, H. J. and Brand, A. (1989): Twinning in dairy cattle: A study of risk factors and effects. Theriogenology 32, 845-862.

Noakes, D. (2009): Pregnancy and parturition: Pregnancy and its diagnosis. In: Noakes, D. E., Parkinson, T. J. and England, G. C. W. (eds) Veterinary Reproduction and Obstetrics. Saunders Elsevier, Philadelphia. p. 93.

Romano, J. E. and Larson, J. E. (2010): Accuracy of Pregnancy Specific Protein-B test for early pregnancy diagnosis in dairy cattle. Theriogenology 74, 932-939.

Sasser, R. G., Ruder, C. A., Ivani, K. A., Butler, J. E. and Hamilton, W. C. (1986): Detection of pregnancy by radioimmunoassay of a novel pregnancy-specific protein in serum of cows and a profile of serum concentrations during gestation. Biol. Reprod. 35, 936-942.

Silva Del Río, N., Stewart, S., Rapnicki, P., Chang, Y. M. and Fricke, P. M. (2007): An observational analysis of twin births, calf sex ratio, and calf mortality in Holstein dairy cattle. J. Dairy Sci. 90, 1255-1264.

Szelényi, Z., Répási, A., de Sousa, N. M., Beckers, J. F. and Szenci, O. (2015): Accuracy of diagnosing double corpora lutea and twin pregnancy by measuring serum progesterone and bovine pregnancy-associated glycoprotein 1 in the first trimester of gestation in dairy cows. Theriogenology 84, 76-81.

Zoli, A. P., Beckers, J. F., Woutersballman, P., Closset, J., Falmagne, P. and Ectors, F. (1991): Purification and characterization of a bovine Pregnancy-Associated Glycoprotein. Biol. Reprod. 45, 1-10. 